\title{
Disaster relief and the Indian state: Lessons for just citizenship
}

\begin{abstract}
$\underline{\text { Abstract }}$
What does the giving and receiving of disaster relief say about a democratic state's engagement with justice and its responsibilities towards its citizens? This is the question that motivates the following paper, where an attempt is made to characterise the "relief state" through the example of the Indian state's response to the super-cyclone in 1999 in Odisha on the eastern coast of India, and more recently, the devastating floods of 2008. The paper interrogates the norms that guide the state in its relief role, as well as the strategies deployed by disaster victims to access such relief. It enquires into whether the framing of disaster relief as a moral obligation of the state and not a formal justiciable right has any bearing on the dispensation of justice by the state towards its citizens.
\end{abstract}

Disaster relief, Citizenship, Justice, Rights, Environment, India

\section{INTRODUCTION:}

A disaster following from a natural hazard reveals a very particular dimension of the relationshhip that a state espouses with its population. State action in the face of a disaster is especially grave as populations are construed as innocent in the wake of a 'natural calamity' that they have no control over and cannot be blamed for causing. Democratic states in particular are obliged to provide relief to their citizens to ameliorate the severity of the effects of a disaster and to help victims cope. As the American President Herbert Hoover remarked in 1935, 'there is no disagreement upon the public obligation to relieve distress which flows from the national calamity' (cited in Landis Dauber, 2013: 11).

Disasters are key political moments in the life of a society (Albala-Bertrand, 1993; Pelling and Dill, 2009). The rich literature on disaster politics has shown that in dealing with disasters, including those that are imminent, states 'marshal their material and discursive powers' in order to gain or improve popular legitimacy (Pelling and Dill, 2009). Only recently, in October 2013, the state government of Odisha, on the eastern coast of India, carried out a massive evacuation exercise of around one million persons living in coastal areas in the line of Cyclone Phailin to places of safety. These were mainly the cyclone shelters that had been meticulously constructed by the state since 1999, the year of the supercyclone which had caught the government by surprise and wreaked immeasurable damage to 
life and property (Chhotray and Few 2012, Samal et al 2005). The state government, generally accustomed to brickbats for poor governance and development performance, acquired a new halo overnight for its heroic efficiency in one of the poorest and most disaster prone states of India ${ }^{1}$.

Even as state obligation to come to the aid of those affected by disaster is generally regarded as incontrovertible, this paper contends that disaster relief as an arena for state action presents a fertile ground for reconsidering older questions around justice as well as citizenship. These are not, as is usually the case, concerns of distributive justice that dominate critical scholarship around vulnerability, risk and disasters (Enarson and Morrow, 1998; Cutter and Finch, 2008; Hilhorst and Bankoff, 2007; Oliver-Smith, 1996; Pelling, 2001 Wisner, Blaikie et al, 2004). Instead, these are to do with the posited qualities of the state as the giver and the individual as the recipient of disaster relief. These attributes are characterised in this paper upon a critical examination of Indian famine codes from colonial times as well as the contemporary relief code, besides empirical research into the Indian state's response to the super-cyclone of 1999 in Odisha and more recently, the devastating floods of 2008.

The state appears as a sympathetic and concerned entity with a clear moral obligation to provide relief to those faced with disaster, but it is careful to circumscribe the terms on which it does so. The recipients of disaster relief are deemed to be deserving of assistance because of their 'innocence' in being subject to a 'natural' calamity; and indeed, even in other contexts like the US, a narrative of 'blameless loss' has been critical to the success of claims for federal money into disaster relief (Landis Dauber, 2013). The relief is provided on gratuitous terms, but care is taken so as to neither subsidise able bodied persons nor interfere with the local moral economy (Dreze, 1994). There is a clear sense of the moral duties of the able recipients of relief to contribute through public works. Accordingly, disaster relief is not a constitutionally prescribed right that is justiciable in a court of law, and has not received legal recognition in India through the six decades since independence. In making claims to accessing relief, recipients have recourse to a moral stance of victimhood, but not to justiciable rights. These aspects of the state and individuals while locked into what I will describe as a 'relief relationship' provoke a discussion about justice and citizenship in India on three grounds.

${ }^{1}$ http://www.indianexpress.com/news/coming-home-after-phailin/1185220/, October 21, 2013 
One, the transition from colonial subject to Indian citizen was based on a premise of equality of civil and political rights, which came simultaneously with independence. However, civil and political rights are 'poor guarantors of substantive equality' in the absence of meaningful social and economic rights within a deeply inegalitarian society divided on the basis of caste, class, gender, religion and ethnicity (Jayal, 2013: 15). This disjunction between equal civil/political citizenship, at least in formal terms, on the one hand, and substantively unequal social citizenship on the other is what marks the experience of citizenship in India as unjust. It also seriously implicates the role of the state in improving the conditions of just social citizenship, whether through the public provision of welfare or the pursuit of redistributive policies. While disasters triggered off by natural calamities may represent a state of exception, they do reflect failures of the state in its responsibilities towards its citizens.

Two, debates around justiciable rights are particularly relevant in India. Equal civil and political rights for all Indian citizens were won at independence and enshrined as justiciable 'fundamental rights' in the Constitution, but the journey to making social and economic rights (SERs) justiciable in law has been precocious and controversial (Jayal, 2013). The state has historically refrained from giving legal recognition to rights involving "positive state action' in the arena of social policy (ibid.). While this has changed dramatically in the last decade, with legal recognition being accorded to the rights of work, education and now food, this comes in an era of general curtailment of public provision in a neoliberal economic climate. The value of justiciable social and economic rights is questionable in the face of staggering obstacles to their realisation. The response of the state in the framing of disaster relief as a moral obligation but not as a legal entitlement must therefore be regarded with reference to how justiciable rights have evolved in India.

Three, the balance between duties or responsibilities and rights is germane to the evolution of citizenship theory and politics in countries like the USA, UK and western European states as well (Lister, 1997). India is no exception. Here, an era of 'social citizenship in neoliberal times' is marked by a 'duties' discourse of citizens as consumers and clients (Jayal 2013, 176). The inculcation of duties was an integral part of the colonial project of 'citizenship education' as much as it was of primary concern to Indian nationalists, albeit in different ways (Jayal, 2013). Duties and rights were 'relegated' to the moral domain within colonial discourse, and contrasted with the political obligation of obedience as a colonial subject, until 
nationalist writers used the moral as a radical political strategy, transposing the duty of obedience into the right to interrogate the colonial state (ibid.).

The moral imperative is equally important for the constitution of rights as is legal obligation, and often (if not always), moral claims and mobilisations precede the enshrining of rights in law $^{2}$. Moral claims are a key part of how rights are negotiated. Partha Chatterjee's (2004) case study of how an association of slum dwellers- effectively urban squatters in Calcuttasuccessfully negotiates welfare benefits from the state is well known in Indian scholarship. Their forging personal, informal connections with influential actors as well as exercising moral pressure to elicit a response to their collective endeavours illustrates the point that citizens do not require formal entitlements to obtain the 'goods of citizenship' ${ }^{3}$. Devaluing moral claims in how citizens experience the state is not explanatorily useful in the Indian context. In this sense, disaster relief provides a novel arena, of aid to victims suffering 'blameless losses' perpetuated by a 'natural calamity', in which to critically consider individual-state relationships. The moral obligation of the state to provide relief is matched by a moral stance of victimhood, and offers an interesting new dimension to the experience of citizenship. Besides, as this paper shows, true to the inegalitarian social context, access to disaster relief does not unfold within a level playing field, and inequalities and social differences within the local political economy are expressed within a particular sort of unjust citizenship.

In essence, this paper is a critical re-reading of Indian citizenship and justice debates from within the perspective of disaster relief. Section 2 characterises the 'relief state' drawing on a discussion of the norms of relief and the duties of citizenship, as well as the politics of natural calamity, section 3 situates the key propositions from this relief relationship within a discussion of 'just citizenship' in India, and section 4 examines the case of disaster relief in Odisha for a rich empirical investigation into how exactly these relationships of giver and recipient are enacted, and with what implications for just citizenship. The conclusion comments on the advantages of viewing disaster relief as an issue of justice.

\footnotetext{
${ }^{2}$ I am grateful to an anonymous reviewer for this point.

${ }^{3}$ Chatterjee extends this point to distinguish between citizens in India into two types: the first that are 'proper' rights bearing citizens inhabiting the domain of civil society, and the second that wield such rights only 'tenuously' and occupy not the civil but a 'political society' (2004). I do not use this typology in this paper, instead choosing to refer to the formal and substantive meanings of citizenship (Holston, 2008; Jayal, 2013), as these are more helpful in drawing attention to the key point being made.
} 


\section{THE RELIEF STATE}

In its characterisation of the 'relief state' in contemporary India, the paper will build on a rich literature concerning the relief functions of the colonial state (Dreze, 1994). The contribution that it seeks to make may be situated within a larger body of research described as 'disaster politics' (Albala-Bertrand, 1993; Pelling and Dill, 2009) especially as the subject of state disaster relief has received rather little attention here (Fred Cuny's 1983 classic titled Disasters and Development remains an exception). Greater emphasis has been placed on the role of international actors in providing humanitarian aid and relief after a severe disaster (Clark, 2005; Korf, 2005; Pelling, 2003). In recent years however, scholars have focused on state relief following major disasters in India (Simpson and Corbridge, 2006; Simpson, 2008 for the Gujarat earthquake of 2001 and Ray-Bennett, 2009; Samal et al, 2005 for the Odisha super-cyclone of 1999).

\subsection{Rationale for disaster relief and the ethics of assistance}

India has a coherent administrative structure for determining and delivering disaster relief. Successive Finance Commissions (constituted every 5 years) have consistently included guidelines on disaster relief, given its salience for centre-state fiscal relations. In 2005, the Parliament passed the National Disaster Management Act that envisaged the creation of the National Disaster Management Authority (NDMA) as the apex body for disaster management in the country (GOI, 2005). The Act sets out the various aspects of state response to a disaster in subsequent phases (such as preparedness, response, evacuation and rescue, relief, rehabilitation and reconstruction amongst others). But while it clarifies the duties and powers of NDMA and the state governments for providing relief, it does not illuminate how exactly the state views its own obligations towards the victims of a disaster.

Clark et al (2012) write that in the international arena, the giving of aid and donations for relief by global actors, western states and their private citizens can exemplify considerations of 'universal generosity', a desire to give for the sake of compassion only and in a manner that 'transcends politics'. This is far from being an adequate framework for understanding why a sovereign state gives disaster relief to its citizens. Since the original Indian constitution does not specifically mention disaster relief, this paper looks to British colonial history and it draws heavily upon Dreze's (1994) analysis of $19^{\text {th }}$ century Famine Codes for this purpose. 
The earliest famine codes were promulgated by the Famine Commission of 1880, with the purpose of giving 'authoritative guidance to the local administration for the anticipation, recognition and relief of famines' (Government of India or GOI 1880 referred to by Dreze, 1994: 82). The Commission expressly titled this as a paternal 'state obligation' since 'there is no doubt that a calamity such as a famine, exceptional in its nature and arising from causes wholly beyond human control......is one which in a country such as India wholly transcends individual effort and the power of resistance' (ibid.: 76). Dreze is wary of concluding this rhetoric of duty was motivated by unbridled humanitarianism alone, and argues that a mix of factors is likely to have influenced this aspect of colonial thinking. These ranged from a desire to preserve political stability and the need to manage public opinion back in England, but also a sense of obligation to a population that was already reeling from the negative effects of colonial expansion (1994: 76). Yet whatever the precise rationale, even as the state expressed obligation, and a duty of care for people trapped in circumstances not of their making, it framed this obligation carefully.

According to Dreze, the clear message contained in the famine codes was as follows: the state would provide relief to the victims of a famine through the organisation of massive public works at subsistence wages to all those who had sought it. Wages would be paid in cash and the works would aim to create 'public assets' such as roads and canals. It was the duty of all able bodied persons to actively seek employment on such works. In addition, there would be 'gratuitous' relief, but only to those who were unable to work on account of their physical conditions (illness, age, disability for example). Gratuitous, as the term connotes, is expressly non-legal and non-contractual and refers to something that has been done 'voluntarily' out of 'kindness or grace' without 'the giver recognising any liability or legal obligation'4. Dreze explains that this arrangement came about after a series of 'self-acting' tests by the Famine Commission to determine which forms of relief (labour in public works, giving of cooked food, cash doles and so on) would be most effective in targeting those who genuinely needed it given the 'weakness of the administrative structure' (1994: 85).

Public works for employment generation were preferred over the other means like cash doles or cooked food, not only because they were more practicable but also as unconditional gratuitous relief was regarded as 'demoralising' (Dreze 1994: 87). This was not because of inherently 'immoral character of gratuitous relief', but for fears of the adverse effects such

\footnotetext{
4 www.m-w.com
} 
relief might have on the existing rural 'moral economy' (Dreze, 1994: 83). The Famine Commission regarded that any unconditional relief must not have the effect of rendering irrelevant the existing practices of mutual assistance. By implication therefore, any gratuitous assistance given by the state should be an adjunct to public charity during the harsh times following a disaster, but not an easy substitute for it. Considerations of financial economy also guided the approach taken by the colonial administrators.

The two key elements of the rationale for disaster relief and the ethics of state assistance are well summarised in the following passage from the Famine Commission Report, 1880.

'.....we have to consider the manner in which the proper recipients of public charity can be most effectually ascertained. The problem to be solved is how to avoid the risk of indiscriminate and demoralising profusion on the one hand, and of insufficient and niggardly assistance on the other- how to relieve all who really need relief, and to waste as little public money as possible in the process' (GOI, 1880 cited in Dreze, 1994: 87).

These basic principles continue to inform the spirit of disaster relief in contemporary India, and as will be shown, the ethics of assistance guiding state policy as well. The Odisha Relief Code (ORC) was derived from amendments made to the Odisha Famine Codes (of 1913 and 1933 ) in 1980, and then again in 1996. At the very outset is a clear declaration of the objectives of disaster relief:

'....to ensure that no one should die of starvation but also to prevent physical deterioration and destitution of the people and to enable them to resume their ordinary pursuits of life on return of better times and simultaneously to encourage the village community in making concerted and continuous efforts to fight a common misfortune. Boosting of the morale of the public in times of disasters is very much necessary (Government of Odisha or GOO, 1996: 2; italics added for emphasis).

The passage reveals a reiteration of the overriding objectives of death prevention through starvation besides the adoption of measures that would enable a resumption of ordinary livelihoods. There is also a strong sense that state relief must complement the efforts of the collective village community to face the disaster, similar to the reference to the rural moral economy mentioned earlier. Moreover, the ORC practically mirrors the Famine Codes in its emphasis on the provision of labour intensive work as the primary relief strategy, wherein 
gratuitous relief is given to those 'who are incapable of earning their livelihood' at the time of a natural calamity, and is in the form of food, clothes, shelter and other basic needs (also known as emergent relief). Then there is ex-gratia assistance given according to clearly devised norms by the central government for different types of loss including: kin, limb or eyes, crops, livestock, means of livelihood (like fishing nets) and so on (GOI, 2010a). Like other types of gratuitous relief, such assistance is strictly given by the state as a voluntary act of kindness. The spirit of such assistance is that the state recognises the loss suffered by the victims of a disaster, and wishes to alleviate their suffering, but ex-gratia assistance is not compensation. This is confirmed by the circulars of the central government.

'Financial assistance in the wake of natural calamities is towards relief and not for compensation of loss.....the main objective of the relief fund is to assist the affected persons to restart their economic activities. On the other hand, compensation is basically replacement of the damage in financial terms. Compensation is a part of a contractual agreement whereby unnatural dispossession of wealth and property is likely to be compensated. Insurance is one of such instruments. It is a legal obligation. On the other hand, relief is by way of gratuitous assistance as an immediate help to overcome the stress. It is generally understood that no country in the world is in position to fully compensate the losses incurred due to natural calamities' (Ministry of Home Affairs, undated circular).

The ethics of assistance are clear. The 'relief state' must not subsidise able bodied people who can take up physical work provided by the state. At the same time, such a state espouses generous concern for those who are not able to work, but is careful to maintain that state help is temporary at a time when normal village practices of mutual assistance are likely to have failed, to the disadvantage of the most vulnerable persons. It is patent that disaster relief is not an entitlement being conferred to citizens who cannot demand it of the state. However, the state's disaster relief is different from charity, and is underpinned by a powerful moral imperative of the relief state bearing responsibility for its citizens.

\subsection{The politics of 'natural calamity'}

At the normative core of the relief state is the idea of a 'natural' calamity, which makes victims of innocent people and makes them deserving of relief and assistance (Landis Dauber, 2013). Yet, a 'natural calamity' serves as a political construct, as evident in the different ways 
that the notion has been put to use by claimants to disaster relief in India and elsewhere. Money is a direct driver for claim-making, and as Landis Dauber writes in the US context, 'it is far better to be standing hip deep in water than to be standing in an employment line' while requesting federal funds (2013: 14). Fate not fault, as she memorably puts it, is what legitimates relief (ibid.). Advocates for an expansion to federal funding at the time of the Great Depression of the 1930s in the US lobbied hard that the Depression should be regarded as a 'national calamity overwhelming the ability of Americans to provide for themselves' (Landis Dauber, 2013: 14).

In India, attempts to conflate 'natural' disasters with 'economic' ones have been generally resisted. Shaped by its colonial legacy, the Indian state has historically accorded great emphasis on the naturalness of the calamity in its relief role. It is meticulous in its efforts to regulate causality between a natural event or trigger and outcome, and what is included in the list of 'natural calamities' is carefully regarded ${ }^{5}$. This approach is reflected in the bureaucratisation of categories of ex-gratia assistance, and the specification of the terms on which such assistance is offered. For example, although a disaster can kill immediately, or injure, traumatise or debilitate leading to death in subsequent weeks/months, the Indian state compensates only for death suffered either on the day or up to three days following the actual event.

The recently passed Disaster Management Act of 2005 has extended the definition of disaster to cover 'man-made causes and accidents' and the focus is on the 'impact' of the calamity, but there is a 'need to have a concrete list of events' under the Act (GOI, 2010b: 200). This still leaves the question of which events and causes make it to the list, and the matter has provoked differences between the central and state governments. Odisha suffers nearly 300400 lightning deaths per year, yet lightning does not appear in the list of calamities listed in the guidelines of the Calamity Relief Fund (CRF), despite several entreaties of the state government ${ }^{6}$. The CRF was established in course of the $9^{\text {th }}$ Finance Commission recommendations (1989-95), on the basis of centre-state contributions in a ratio of 75:25. The $11^{\text {th }}$ Finance Commission (2000-2005) also created the National Calamity Contingency Fund

\footnotetext{
${ }^{5}$ Relief Commissions have sometimes gone beyond this strict reading of a 'natural calamity' in their actual work. The Special Relief Commissioner, Odisha, revealed that they had organized and run relief camps for a year in Kandhamal district in Odisha, the site of terrible Hindu-Christian conflicts, even though it was a 'manmade disaster' (Interview, Bhubaneswar, December 2009).

${ }^{6}$ Interview with official at the Special Relief Commission, Cuttack, December 2009.
} 
(NCCF) to provide assistance to states for calamities of the 'rarest severity' beyond that which can be met by the CRF.

The politics of natural calamity is most clearly played at out at the level of centre-state fiscal relationships, and disaster relief is the joint responsibility of the centre as well as of states in India. The labelling of a calamity as 'national' is heavily politicised with ruling parties in the affected states and their counterparts at the centre active seeking this label. A national calamity is no longer the responsibility of the state government alone, and warrants discretionary funding from the central government. In 1999, the BJP government at the centre declared the super-cyclone to be a 'national calamity' on October 31, two days after it struck the coast of Odisha, and the PM also announced a billion rupees from the National Fund for Calamity Relief as an appropriate response to the 'extraordinary situation' being experienced in Odisha. By the 13th of November, Congress party politicians (in power in Odisha) were clamouring for the disaster to be 'treated' as a national calamity, on the grounds that mere lip-service of declaration was not enough. They argued that it should be used effectively to get 'international funds' for reconstruction, including soft loans from the World Bank (New Indian Express or $\mathrm{NIE}^{7}$, November 13, accessed November 2009).

Although money did pour in from various international donors (and these figures have not been aggregated by the government), in the end, the state received less money from the central government than it had requested. Figures released by the state government placed the amount of cash received at 828.15 crore $^{8}$ rupees, a fraction of the 6243.956 crores that were demanded. Years after the super-cyclone, key state bureaucrats have openly spoken of their discontent with the 'stepmotherly' treatment doled out by the centre, which is seen both to disburse more funds, and more promptly, to other states than to Odisha ${ }^{9}$. The state has also been conspicuous by its absence from the list of recipients of Additional Central Assistance (ACA) that is given for post-disaster reconstruction in severe calamities: other recipients include Gujarat after the 2001 earthquake, Tamil Nadu after the 2004 Tsunami, Kashmir after the 2005 earthquake and Bihar after the 2008 Kosi floods. And yet, Odisha, a significantly disaster prone state that has remained marginal to national politics relative to the populous Hindi heartland and several southern states, is now leading the way in terms of disaster

\footnotetext{
${ }^{7}$ All subsequent newspaper articles from the NIE referred to in the paper will only mention the mention the month and date; the year is 1999 for all.

${ }^{8}$ A crore equals ten million.

${ }^{9}$ Interview with Special Relief Commissioner, Bhubaneswar, December 2009.
} 
mitigation and preparedness at the national level (Chhotray et al, 2013), and this may well change its leverage on financing for disaster relief.

While investigating these issues in depth has not been the subject of this paper, these bear mention here in order to draw attention to the realpolitik that constrains the financing of disaster relief by the state. Despite the moral appeal of disasters and their potential to mobilise tremendous resources from the state, an intangible (if negotiable) ceiling of available money promotes considerations of financial economy in state response to disasters. This too contributes to the discussion on why disaster relief is not a legally enforceable right, and links with a larger issue of the legal enforceability of social and economic rights (SERs). This takes us into the heart of the next section, where I situate central propositions from the working of the relief state within Indian citizenship and justice debates at large.

\section{JUST CITIZENSHIP AND RIGHTS: A CONTESTED INDIAN HISTORY}

'The empirical specificity of citizenship consistently undermines its normative claim of universality', writes Jayal (2013: 6). Citizenship is about the ways in which 'states relate to the members of the population over which they govern' (ibid.), and the particular elements making up a 'regime of citizenship' will vary across different societies, and even within the same society over time. All citizenships however are deeply concerned with the management of social differences. The 'substantive distribution' of rights amongst members formally incorporated as citizens of a nation-state depends on the meanings of equality and inequality in that society (Holston, 2008). In India, formal equality of civil and political rights is marred by significant substantive inequalities in the distribution of social and economic rights (SERs). Unjust citizenship in India refers to unjust social citizenship. The deeply unequal consequences of disasters confirm this injustice, and firmly situate the experiences of disaster victims within the canvass of social citizenship in India. How then can we interpret the relationship between the state as giver and the individual as a recipient of disaster relief through what we know of how the Indian state has addressed the issue of just citizenship?

Both before and after independence, the story of SERs is one of political negotiation and compromise (Jayal, 2013). In the 1930s, debates in the Constituent Assembly tasked with the drafting of the Indian Constitution referred to a classification of rights between those that could be legally enforced, and those that could not. Extended arguments crystallised down to the view that there had to be a conceptual distinction between civil and political rights which mandate negative guarantees from the state, and social and economic rights, which require 
positive state action (ibid.). Constitutional propriety and practicability became the two principal grounds on which civil and political rights went on to constitute the justiciable Fundamental Rights and social and economic rights were housed in the non-justiciable Directive Principles of State Policy.

There were two objections within constitutional propriety: SERs, it was felt were ideological, and 'lacked political neutrality', and should not be given the 'status of rights' but left as directives for state action, to be settled within the democratic political process (Jayal, 2013: 154). In the same vein, advocates of this distinction also distinguished between 'policies and rights', and while rights could be constitutionally guaranteed, policies could not and ought therefore not to be mandated within a constitutional document. Arguments about practicability and enforceability centred on a dubious distinction between negative and positive state action, where the latter is necessary for SERs but 'is unaffordable in a resource poor country, and/or unenforceable through courts' (Jayal 2013: 156). These issues have been deeply contentious, with critics pointing out that all rights mandate a measure of both negative and positive intervention by the state. Gandhians and socialists bitterly attacked this division and cried that the Indian constitution had failed the poor.

In independent India, a welfare state treated welfare as a matter of 'official largesse' even 'charity', but delinked the entire subject from a serious consideration of SERs (Jayal, 2013: 167-168). The severance of the civil and political from the social and economic amounted to an artificial bifurcation of a composite realm of citizens' rights. It led to an approach to welfare on the basis of 'categories of exceptional provision' (Jayal, 2013: 169), such as backward classes, tribes, minorities from colonial times, and later newer categories like small and marginal farmers, artisans, women and children and so on. The unmistakable irony of restricting SERs to those deemed as 'deserving' in special 'boxes' was that all those who were not in these boxes were well provided enough anyway not to require such assistance. Moreover, by not being universal, social and economic provisioning never took the form of rights at all, and did not 'attach to citizenship in the way in which civil and political rights were integrally linked with it (Jayal, 2013: 170). This trend has continued with the addition of new and contentious categories of assistance in the form of the 'Below Poverty Line' in 1997.

The post reform period since the adoption of economic liberalisation in India in 1991 has seen a curious emphasis on rights in various core areas of social policy, within a climate of general reduction in social provisioning by the state (Harriss, 2011). Education is no longer 
contained within the Directive Principles of State Policy, and the right to education- free and compulsory- is a fundamental right for all children from age six to fourteen. However, discussions on other 'new rights' like the right to work and possibly the right to food have been plagued by deep divisions regarding universality and affordability. The right to work under the National Rural Employment Guarantee Act 2006 is universal in theory, but depends on self-selection by those willing to work for the minimum wage. The National Food Security Act, 2013, extends the entitlement to receive subsidised food grains to two thirds of the population through a targeted public distribution system (PDS) (with special provisions for children of all ages in addition to four additional categories of people including migrants, homeless, the urban poor and emergency and disaster affected persons'). So while there is a 'perfunctory nod in the direction of universalism', it will not be universal (Jayal, 2013: 181).

Targeting versus universalism in social provisioning has vigorously engaged academic scholars and politicians in India alike, (Dreze and Sen, 2013; Panagariya and Bhagwati, 2012), and the arguments have been trenchant in the run up to the national elections in 2014. While it is not the purpose of this paper to refer to this debate in detail, one salient point of relevance here is what targeting does to the question of citizenship at large. Evidence from social welfare policy in Europe, where universalism has been a very influential principle, suggests that this has 'been most critical for securing the political support of the middle classes for the welfare state' (Judt, 2010 cited in Dreze and Sen, 2013: 195). Improved social achievements in a number of India's most progressive states, like Himachal Pradesh, Kerala and Tamil Nadu, are also based on 'universalistic and inclusive social policies' (Dreze and Sen, 2013: 194). Targeting and the selective provision of services are detrimental to civil solidarity (Jayal, 2013). Without the social consensus that no individual can be allowed to fall below a certain minimum level of well-being, targeted welfare provision makes the society appear to be less cohesive as some citizens resent having to contribute towards this purpose (ibid.).

There are significant obstacles to the realisation of SERs, both those that have been considered for legal recognition and those that have not. As such, there are searing criticisms that rights for social citizenship are being used to manage popular discontent in the face of growing inequalities and are nothing but a legitimating device to soften the harsh effects of capitalism (Marshall, 1950; Jayal, 2013). Yet, there is general agreement that the 'opportunity for appeal to the courts against the violation or non-provision of social rights' afforded by these new social rights is an unambiguous good (Jayal, 2013: 195). Access to the formal 
justice system remains extremely difficult though, and the few successful cases are a result of proactive lobbying by an engaged civil society constituting various active citizens groups.

This brief peak into state action for just citizenship in India suggests that 'justiciability' of social and economic rights has been a contentious process, and even when legal recognition has come, on cautious terms, the original severance of SERs from universal full bodied civil and political rights has undermined their coverage and strength. Interpreting the absence of justiciable rights to disaster relief within this history of rights in India becomes much easier. However, the absence of justiciable rights in the arena of disaster relief is juxtaposed with the presence of discernible moral claims for citizens in their temporary roles as disaster victims. The final section of this paper considers the terrain of citizenship as enacted through these moral claims, in the aftermath of a disaster, and teases out the principal conclusions for justice.

\section{CITIZENSHIP AS VICTIMHOOD: POST-CYCLONE ODISHA}

The famine and relief codes of India, as discussed in section 2, contained more than the obligation of the state towards disaster victims. These also included a clear moral code of conduct for the victims themselves: able bodied persons would actively seek work on public works provided by the state, and for those unable to work, gratuitous relief would be granted for a limited period of time until the resumption of usual practices of mutual assistance expected within the moral economy of the village. The emphasis was on deservedness to generous state assistance but equally on duty, to participate in work and to help one another. This research suggests that disaster victims exercise a very distinctive type of citizenship practice and behaviour, drawing on their moral stance of victimhood, at times in stark contrast to this moral code. Even as disaster victims and the state enter into a transient 'relief relationship' with distinctive elements, several key elements of their behaviour and of the processes that unfold only reiterate the extremely unequal social context and local political economy. Citizenship as victimhood, this section suggests, is yet another version of the unjust citizenship that this paper has previously detailed.

In this section, I describe the behaviour of cyclone victims in November 1999 and of flood victims in September-October 2008, as told to the research team in interviews ${ }^{10}$ during

\footnotetext{
${ }^{10}$ This paper draws on field research conducted for a year long UNDP India supported research project 'Sociopolitical and environmental dimensions of vulnerability and recovery: critical lessons since the super-cyclone of 1999 ' in 2010-11.
} 
fieldwork in 2010 besides accounts from the popular press. When the super-cyclone struck the coast of Odisha in 1999, people helped each other a lot during the event, sheltering together in a few concrete structures, and assisting one another with setting up some temporary tarpaulin and bamboo structures (Chhotray et al, 2013). It took days, and in many places, weeks for the state to reach its relief provisions to disaster victims. Not only were there physical hurdles like damaged roads, collapsed trees and flash floods which made relief delivery difficult, there was also the severely anti-social behaviour of desperate and opportunistic sections of the affected populations that engaged in widespread looting of food and other essential commodities from relief trucks ${ }^{11}$. Such aggressive behaviour amounting to vandalism grew more audacious with each passing day in the immediate aftermath of the super-cyclone. It led to the virtual abandonment of trucks on principal roads, including the national highway number 5 from the capital city (Bhubaneswar) to other major towns (Cuttack). Roadside villages closer to district headquarters were at an obvious advantage here, and trucks meant to take relief into interior villages on the sea coast often never reached their destination.

The state responded by strengthening security visibly, with armed police vehicles being sent to accompany relief materials (NIE, November 3). The state vigilance department got involved, and formed 'eight special squads' to ensure the smooth distribution of relief materials and also to stop the hoarding and black marketing of essential commodities (NIE, November 4). Realising the limits of its measures, the state appealed to the people for selfvigilantism, to 'control' the anti-social elements. Very soon, looting became a public order issue and the state government had to resort to airdropping essentials, which immediately put more able-bodied victims ahead in the game. Intense fighting broke out when the odd relief truck arrived in roadside villages in the worst affected block (Erasama in Jagatsinghpur district). These men also prevented the trucks from reaching remote, sea-side villages, whose residents bitterly recall these incidents even ten years later. Relief materials were also routinely stolen from ill-secured panchayat ${ }^{12}$ buildings. Above the chaos, there were fights over 'criteria' for distribution, which were neither clearly laid down by the panchayat functionaries in charge, nor understood by the gathered crowds.

\footnotetext{
${ }^{11}$ Similar experiences have been reported after disasters in other places too; such as Gujarat after the 2001 earthquake (Simpson, 2008).

${ }^{12}$ A three tier system of elected local self-government at the district, block and village levels in India.
} 
If violent aggression on the part of men was one side to the claiming of disaster relief as victims, passive victimhood in the form of beggary on the part of the old, the infirm and other vulnerable sections was another. On November 16, 1999, the NIE reported how people, especially the elderly, injured and sick, 'crawled out of their collapsed houses to beg for food and polythene'. Desperate villagers also lay down their children on the roads as a part of their begging tactics. They abandoned and disowned their old parents to make them 'eligible' for assistance from NGOs targeted for those without any family. These actions established the extremely dehumanising character of the experience that is relief, and represented a low point in the relationship between people and the relief state. Since 1999, the Odisha state government has taken several important measures to make relief delivery more effective through improvements in road networks, better levels of emergency food stocks, and superior coordination amongst relief officials. Fewer incidents of looting and beggary were reported after the 2008 floods, and remotely located villages were better served, yet the mechanics of relief access still disadvantage women, the infirm and elderly persons. General ill-being and trauma after a disaster and the physically arduous nature of queuing up for relief, even when distributed relatively peacefully, continue to be the major constraining factors.

While this first stage of relief provision and access often involved such blatant victimhood expressed through looting and beggary, by the second stage, a more complex form of such 'citizenship as victimhood' practice had emerged. The latter stage of relief follows after the immediate aftermath of a disaster, when victims weigh the damage suffered and seek exgratia assistance from the state for losses in different pre-determined categories. The politics of assessment for potential disaster related benefits tended to follow a similar pattern to those observed for the more usual certifications of poverty for welfare benefits (Corbridge et al, 2005). Much like with regular welfare schemes, poorer households were also severely disadvantaged by their inability to command the means needed to influence critical gatekeepers in order to obtain these benefits (Pattenden, 2011 for a discussion on 'gatekeeping' in India). Being a relief state however, the Odisha government itself adopted a stance of uncharacteristic leniency in its response to individual strategies to gain access to more relief. Some examples of the Odisha state's behaviour in this respect will illustrate.

After the super-cyclone, assistance was given for damage to house and loss of kin. Revenue Inspectors (RIs) - local officials responsible for land tax collection and land registration- were given the difficult task of field level assessments and drawing up the list of claimants of ex- 
gratia assistance. Though there were apparently few problems associated with the disbursement of ex-gratia assistance for damaged mud or kutcha houses (a modest 3500 rupees for a fully damaged house), many respondents recalled discrepancies especially with respect to receipts of ex-gratia for the loss of kin, where larger amounts (75,000 rupees per life lost) were involved. People openly blamed the RIs, but also tehsildars (block level revenue officials), sarpanches and government lawyers, for colluding to exploit hapless victims and exploiting the general chaos and lack of transparency. For example, one man in Kalabedi, a small coastal village within Erasama block, who had lost his mother in the cyclone, claimed to have paid 15,000 rupees in all (to lawyer, sarpanch and tehsildar) in order to have various documents signed and processed.

Assessment procedures have been considerably 'tightened' in the years since. In 2008, the Special Relief Commissioner of Odisha decided to send out composite teams of assessors, and not the lone RI, with the aim of creating an environment of mutual vigilance during assessment. The decision was also taken to make payments by cheque, and stop cash payments altogether, in a bid to minimise cuts for RIs and sarpanches. Despite these innovative measures, primary research undertaken after the 2008 floods showed that the possibilities for discretion in assessment remained. By this time, the Government of India had begun awarding ex-gratia assistance after a disaster in more categories, including personal injury, crop loss and loss of livelihoods means (such as artisanal trade equipment). The amounts awarded were also larger than in 1999. Research in Garadpur block of Kendrapara district revealed numerous cases of 'full' house damage assistance being sanctioned, when only 'partial' damage or even no damage had been suffered. Assistance for crop loss beyond the prescribed ceiling had also been given to larger landowners, whereas many smallholders did not receive the prescribed minimum assistance. People manipulated their situation actively, and were often guilty of voluntarily offering to pay bribes to assessors even when none were demanded.

The most common malpractice was to bribe the RI a sum of money, often with the connivance of his junior staff such as a peon, and seek inclusion in the 'full damage to house' list. Not everyone was clear about what was being offered or what they were due, which led to further offers of incentive payments by recipients. Despite this lack of clarity, people were generally aware of the major categories of assistance on offer, and did their utmost to claim these as best as they could. This echoed the strategies adopted by prospect recipients of benefits under regular state development schemes. Much like people who seek inclusion in 
the state's Below Poverty Line list (BPL), even when they did not meet official criteria, many recipients of disaster relief manipulated their positions and connections to extract state resources for themselves. This severely disadvantaged those without the cash or connections to influence the gatekeepers to these resources. The experience of disaster relief only echoed the injustice of social citizenship. Material or economic inequalities were accompanied by stark differentiation by gender and age.

As the hapless victims of loss, those who could were able to able to go further, vindicated by their moral stance, genuine as well as adopted. Indeed, the strategic use of loss as a resource to bargain for more assistance from the state is carried out in the full knowledge that such assistance is not really a right with a definitive meaning and extent, but a temporary bounty, the provenance of which lay in the disaster itself. This was matched by a stance of leniency from the state, which would be unheard of for regular development schemes. After the 2008 floods, the Special Relief Commission issued an instruction to all Revenue Inspectors to 'err on the side of generosity' while assessing damage ${ }^{13}$. At the same time, such leniency was not countenanced in all aspects of disaster relief operations, and certainly people were not able to bargain for amounts greater than those set out in the CRF norms. There were one or two reported cases where recipients, angered by the successful manipulation of a few dominant persons, took on an active role as 'aware citizens' by complaining to the district administration for actions to be taken against corrupt lower functionaries.

Finally, the case of sharecroppers illustrates well the unjust citizenship embodied by disaster relief. Assistance for crop loss has been introduced for disaster victims by the new CRF norms of 2009. In Odisha, the state government awarded such assistance for the first time since the October 2008 floods. According to the CRF guidelines, farmers had to be able to produce formal ownership records (known as land pattas) in order to qualify for assistance. This gravely disadvantaged sharecroppers who typically have no formal proof of their sharecropping arrangements, and yet sharecropping is widely practised throughout India in such informal terms. Primary research in Garadpur block of flood affected Kendrapara district revealed that sharecroppers invest in seeds, fertilisers and other input costs, but receive nothing if the crop is destroyed by a flood. Any crop loss assistance is pocketed solely by the landowner. The research also did not encounter any cases where landowners willingly gave sharecroppers a portion of the input subsidy. This raises questions of the

${ }^{13}$ As reported by the senior official himself in a public workshop in Bhubaneswar, November, 2010. 
degree to which different categories of beneficiaries are rendered visible to the state: landholders with proof of land ownership are 'visible' in bureaucratic terms but tenant cultivators or sharecroppers embedded in informal relationships are not. State officials were well aware of this, but were unable and/or unwilling to do anything concrete about this, and there have no concrete changes to the officials guidelines till date, despite shows of good intent. For instance, the then Special Relief Commissioner, GOO, said his office would be happy to provide ex-gratia assistance to sharecroppers who could submit proof of their tenancy arrangements.

\section{CONCLUSION}

Disasters reiterate social injustices by impacting upon differently positioned individuals and groups unequally. This paper brings a novel perspective to the discussion of disasters in terms of justice by turning the spotlight on disaster relief by the nation-state, using the case of India. It focuses on the relationship that develops between the state as the giver of disaster relief and the individual as its worthy recipient, and delineates their distinctive attributes in these roles. It relies on a reading of colonial famine and contemporary relief codes respectively to characterise the Indian 'relief' state to arrive at the following problem: did the framing of disaster relief as a moral obligation but not as a justiciable right matter in the state's dispensation of justice?

To answer this question, the paper launches into a larger discussion about the Indian state's approach towards social and economic rights for its citizens. Equal civil and political rights for all Indian citizens were guaranteed by the constitution, but not social and economic rights which did not 'attach' to Indian citizenship in the same way. Substantive inequalities in the social and economic domain are the hallmark of unjust citizenship in India, without which citizens do not experience the full benefits of equal civil and political rights. The paper discusses how the justiciability of SERs has been a troubled issue right from the Constituent Assembly debates preceding the framing of the constitution, with doubts being cast on the grounds of constitutional propriety of including rights that required expansive, positive state action as well as practicability, both affordability and enforceability. 
Hesitation to attach constitutional weight to positive state action to enforce universal social and economic rights continued well after independence. The Indian state is a welfare state, but welfare itself was disbursed as charity, with special categories of exception of those who were needy enough to be deserving of state social provision. The irony was that SERs were the preserve of those who could not participate in the formal conditions of equal citizenship, and those who were well enough to, did not need these special SERs. In the recent and somewhat curious emphasis on SERs in the era of economic liberalisation and neoliberal reform, when rights to education, work and food, have received legal recognition (and the right to education is now a fundamental right), also the process has continued to be divorced from inclusive universal social provisioning. The criticism that without the political and social consensus needed to ensure a common minimum standard of dignity and well-being there can be no just social citizenship is a compelling one. Moreover, without the conditions in place for the realisation of SERs, the value of legal recognition is in itself contested.

This brief history of SERs in India helps to explain why disaster relief, in essence a social and economic right, has not been constituted as a justiciable right. Moreover, as the paper shows, the politics of natural calamity heavily impacts upon the financing of disaster relief, and there are massive constraints to resources that states can command for this purpose. And yet, disasters are not ordinary events; they are accompanied by a powerful narrative of 'blameless loss' for innocent victims and the Indian state is compelled to come to the assistance of those affected. This moral imperative is far from being a weak anchoring for state action, and there is far more public support for state response to disasters than 'routine welfare'. Disaster victims can and do exercise a moral stance of deservedness while claiming state attention, even leniency. This, the paper contends, constitutes an interesting new dimension to the experience of citizenship as 'victimhood' in India. 
To substantiate this notion, the paper draws from rich evidence in post-cyclone Odisha where the experiences of accessing relief are marked by a range of behaviours, not all of which fulfil the moral expectations around duty to work and assist others implicitly contained in the famine/relief codes. In the experience of hostility and aggression, looting and beggary, disaster victims displayed the different contours of citizenship as victimhood, and adopted a particularly desperate mode of behaviour that only a disaster can elicit. In the relatively calmer and more calculated phase of negotiating ex-gratia assistance for loss, disaster victims suffered the usual experiences of collusion and corruptions by local officials, with the difference that the 'victims' too exploited a moral position of deservedness to cheat and dupe local officials to get more. And yet, in both these contexts, access to disaster relief was severely differentiated, and those with better resources and connections to gatekeepers, as well as physical strength, fared better. There was no way of ensuring a dignified and equitable experience of relief.

In the final analysis, the paper concludes that disaster relief re-enacts unjust citizenship, much like any other arena of state-individual relationship in India. The lack of a justiciable social and economic right is not any more evidence of the lack of dispensation of justice by the state towards its citizens, than it is an affirmation of the approach taken to social citizenship in India. Besides, it is not entirely clear either, if there would be discernible advantages in the legal recognition of disaster relief. Would it be helpful if the Indian state were to identify special categories of exception amongst the disaster affected peoples to allocate rights, and make these justiciable in a court of law? The difficulties that citizens regularly face in dealing with the courts in this country make this a sobering proposition. A much more compelling issue is that the worst effects of a disaster are generally experienced by those who are also the worst sufferers of niggardly, poorly executed and exclusionary social provisioning. Disasters are unkind mirrors to society, and very quickly reveal the debasing and unjust character of citizenship. Any serious attempt to address the injustices of disasters cannot be restricted to making disaster relief a justiciable right, and must involve a larger conversation about the role of the state in improving the conditions of just social citizenship, whether through the public provision of welfare or the pursuit of redistributive policies. This is the biggest lesson of viewing disaster relief as an arena of justice. 


\section{References}

Albala-Bertrand, J.M. 1993. Political Economy of Large Natural Disasters: with Special Reference to Developing Countries. Clarendon Press, Oxford.

Baviskar, A., Sinha, S and Philip, K. 2006. Rethinking Indian Environmentalism: Industrial Pollution in Delhi and Fisheries in Kerala. In: Bauer, J.R. (Ed.) Forging environmentalism: Justice, livelihood and contested environments. M.E.Sharpe, USA, pp. 189-256.

Chatterjee, P. 2004. The Politics of the Governed: Reflections on Popular Politics in Most of the World. Columbia University Press, New York.

Chhotray, V. and Few, R. 2012. Post-disaster recovery and "ongoing” vulnerability: Ten years after the super-cyclone of 1999 in Orissa, India. Global Environmental Change, http://dx.doi.org/10.1016/j.gloenvcha.2012.05.001

Chhotray, V. and Hill, J., Biswal, R. and Behera, S. 2013. Socio-political and environmental dimensions of vulnerability and recovery in coastal Orissa: Critical lessons since the 1999 super-cyclone. http://www.uea.ac.uk/internationaldevelopment/People/staffresearch/odisha+final+report

Clark, N.H. 2005. The Indian Ocean Tsunami: Geographical Commentaries One Year On. The Geographical Journal 171(4), 369-386.

Clark, N., Chhotray, V. and Few, R. 2012 'Disaster risk reduction and global justice', The Geographical Journal, doi: 10.1111/geoj.12005

Corbridge, S., Williams, G., Srivastava, M. and Veron, R. 2005. Seeing the State: Governance and Governmentality in India. Cambridge University Press, Cambridge.

Cuny, F. 1983. Disasters and development. Oxford University Press, USA.

Cutter, S. and Finch, C. 2008. Temporal and Spatial Changes in Social Vulnerability to Natural Hazards. Proceedings of the National Academy of Sciences of the United States of America 105(7), 2301-2306.

Dreze, J. 1994. Famine Prevention in India. In: Dreze, J., Sen, A. and Hussain, A. (Eds) The Political Economy of Hunger: Selected Essays. Oxford University Press, New Delhi, pp. 69177.

Dreze, J. and Sen, A. 2013. An uncertain glory: India and its contradictions. Princeton University Press, Princeton.

Enarson, E. and Morrow, B.H. eds. 1998. The Gendered Terrain of Disaster: Through Women's Eyes. Laboratory for social and behavioural research, Florida International University, Miami, Florida. 
Government of Odisha 1996. The Odisha Relief Code. Revenue Department, Bhubaneswar.

Government of India 2005. National Disaster Management Act. National Disaster Management Authority, Ministry of Home Affairs, New Delhi http://www.ndmindia.nic.in/acts-rules/DisasterManagementAct2005.pdf

Government of India 2010a. Items and Norms of Assistance from the Calamity Relief Fund and National Calamity Contingency Fund for the Period between 2005-10. Lok Nayak Bhawan, Ministry of Home Affairs, New Delhi.

Government of India 2010b. Recommendations of the 13th Finance Commission of India. Ministry of Finance, New Delhi.

Harriss, J. 2011. How far have India's economic reforms been guided by 'compassion and justice'? Social policy in the neoliberal era. In: Ruparelia, S. Reddy, S., Harriss, J. and Corbridge, S. (Eds.) Understanding India's Political Economy: A great transformation. Routledge, Oxon, pp. 127-140.

Holston, J. 2008 Insurgent citizenship: Disjunctions of democracy and modernity in Brazil. Princeton University Press, Princeton.

Hilhorst, D. and Bankoff, G. 2007. Introduction: Mapping Vulnerability. In: Bankoff,, G., Frerks, G. and Hilhorst, D. (Eds) Mapping Vulnerability: Disasters, Development and People. Earthscan, Trowbridge, pp 1-9.

Jayal, N. 2013. Citizenship and its discontents: An Indian history. Harvard University Press, Massachussetts.

Korf, B. 2005. Antinomies of Generosity: Moral Geographies and post-Tsunami aid in South-east Asia. Geoforum 38(1), 366-378.

Landis Dauber, M. 2013. The sympathetic state: Disaster relief and the origins of the American Welfare State. Chicago University Press, Chicago.

Marshall, T.H. 1950. Citizenship and social class: And other essays. Cambridge University Press, Cambridge.

Oliver-Smith, A. 1996. Anthropological Research on Hazards and Disasters. Annual Review of Anthropology 25, 303-328.

Pattenden, J. 2011. Gatekeeping as Accumulation and Domination: Decentralization and Class Relations in Rural South India. Journal of Agrarian Change 11(2), 164-194.

Panagariya, A. and Bhagwati, J. 2012. India's tryst with destiny: Debunking myths that undermine progress and addressing new challenges. Collins Business.

Pelling, M. 2001. Natural disasters? In: Castree, N. and Braun, B. (Eds) Social Nature: Theory, Practice and Politics. Wiley-Blackwell, Oxford, pp. 170-188. 
Pelling, M. ed. 2003. Natural disasters and development in a globalizing world. Routledge, London.

Pelling, M. and Dill, K. 2009. Disaster Politics: Tipping points for Change in the Adaptation of Socio-political Regime. Progress in Human Geography.

http://phg.sagepub.com/content/early/2009/05/12/0309132509105004 (accessed 15th

February 2011)

Ray-Bennett, N. 2009. Caste, Class and Gender in Multiple Disasters: The Experiences of Women Headed Households in an Oriya village, India. VDM, Germany.

Samal, K.C., Meher, S., Panigrahi, N. and Mohanty, S. 2005 State, NGOs and Disaster Management. Rawat Publications, New Delhi.

Simpson, E. and Corbridge, S. 2006. The Geography of Things that may become Memories:

The 2001 Earthquake in Kachchh-Gujarat and the Politics of Rehabilitation in the Prememorial era. Annals of the Association of American Geographers 96(3), 566-585.

Simpson, E. 2008. The Rise and Fall of Collective Public action in the Aftermath of the Gujarat earthquake of 2001. Non Governmental Public Action Programme Working Papers No 11. London School of Economics, London.

Stanford Encyclopedia of Philosophy 2011. Rights. http://plato.stanford.edu/entries/rights/ Wisner, B., P. Blaikie, T. Cannon and I. Davis. 2004. At risk: Natural hazards, People's Vulnerability and Disasters. Routledge, London and New York, 2nd edition. 